\title{
TINGKAT KEPUASAN KONSUMEN RESTORAN PONDOK HIJAU KOTA MANADO
}

\author{
Arthur Hardyasar \\ Juliana R. Mandei \\ Joachim N.K. Dumais
}

\begin{abstract}
ABSRACT
This study aims to measure the level of customer satisfaction of green cottage restaurant viewed from the aspect of product, price, place, promotion and service. This research was conducted from February to April 2017, using primary and secondary data with sampling technique of accidental sampling method and respondents were 96 people. The method of analysis used is descriptive data analysis depicting Level of Consumer Satisfaction at Restaurant Pondok Hijau Manado City. To measure the Level of Consumer Satisfaction at Restaurant Pondok Hijau Manado City, use the Likert Scale. The result of the research showed that the perception index of customer satisfaction to the service of distribution for credit of grassroot business at Bank BRI Unit Tomohon Utara Tomoho City, Consumer Satisfaction Level of Pondok Hijau Restaurant in Manado was $76.64 \%$ and classified as Very Satisfied $(S P)$.
\end{abstract}

Keywords: Satisfaction Level, Consumer, Restaurant, Pondok Hijau, Manado City

\begin{abstract}
ABSTRAK
Penelitian ini bertujuan untuk untuk mengukur tingkat kepuasan konsumen restoran pondok hijau dilihat dari aspek product, price, place, promotion dan service. Penelitian ini dilaksanakan pada bulan Februari sampai April 2017, menggunakan data primer dan sekunder dengan teknik pengambilan sampel metode accidental sampling dan responden sebanyak 96 orang. Metode analisis yang digunakan adalah analisis data deskriptif yang menggambarkan Tingkat Kepuasan Konsumen Restoran Pondok Hijau Kota Manado. Untuk mengukur Tingkat Kepuasan Konsumen Restoran Pondok Hijau Kota Manado, di gunakan Skala Likert. Hasil penelitian menunjukkan bahwa angka indeks persepsi kepuasan nasabah terhadap pelayanan penyaluran kredit usaha rakyat pada Bank BRI Unit Tomohon Utara Kota Tomohon Tingkat Kepuasan Konsumen Restoran Pondok Hijau Kota Manado adalah sebesar $76.64 \%$ dan tergolong Sangat Puas (SP).
\end{abstract}

Kata kunci: Tingkat Kepuasan, Konsumen, Restoran, Pondok Hijau, Kota Manado 


\section{PENDAHULUAN}

\section{Latar Belakang}

Saat ini banyak usaha yang sudah berkembang dengan pesat, hal ini disebabkan dengan adanya ide kreatif dan inovatif. Seiring dengan ide tersebut konsep pemasaran pun turut berkembang. Kegiatan pemasaran sekarang sudah mulai difokuskan pada kepuasan konsumen. Pada umumnya setiap usaha bertujuan untuk mencari keuntungan, tujuan tersebut tidak terlepas dari kegiatan pemasaran. Pemasaran itu sendiri sudah harus dipikirkan sebelumnya, agar lebih tepat pada sasaran konsumen. Karena konsumen yang potensial akan mempertimbangkan berbagai faktor, diantaranya faktor kualitas produk sehingga membuat konsumen merasa sangat puas dan lebih memilih produk kita daripada produk pesaing yang lain (Hayati dan Sekartaji, 2015). Persaingan yang semakin ketat, dimana semakin banyak produsen yang terlibat dalam pemenuhan kebutuhan dan keinginan konsumen, menyebabkan setiap perusahaan harus menempatkan orientasi pada kepuasaan pelanggan sebagai tujuan utama (Tjiptono dalam Sari, 2012). Semakin maraknya persaingan kepuasan dan ketidakpuasan konsumen sebagai tujuan utamanya. Tidak terkecuali dalam usaha kuliner yang dimulai dari skala kecil seperti warung-warung dan cafe tenda bisnis makanan berskala menengah seperti depot, rumah makan dan cafe sampai dengan bisnis makanan yang berskala besar seperti restoran-restoran di hotel berbintang. Bisnis restoran saat ini termasuk salah satu bisnis yang paling digemari. Hal ini dapat dibuktikan dari banyaknya restoran-restoran baru yang bermunculan pada beberapa tahun terakhir. Setiap restoran berusaha menonjolkan keunikan mereka masing-masing, baik dalam gaya penyajian maupun dalam menu yang disediakan.

Kota Manado adalah pusat bisnis restoran atau kuliner di Sulawesi Utara yang juga di kenal dengar kota ekowisata sehingga banyak pengunjung yang datang setiap tahunnya. Masyarakat Manado yang di kenal dengan masyarakat yang hobi makan dan hal inilah yang membuat bisnis kuliner bertumbuh pesat. Salah satu bisnis kuliner yang ada di kota Manado yang menunya sangat bervariasi. Salah satunya adalah Restoran Pondok Hijau. Restoranan Pondok Hijau ini menyajikan makanan yang berasal dari bahan utama yaitu ikan air tawaran seafood dengan menghasilkan produk makanan seperti ikan mujair yang dibakar, udang bakar rica, cumi saus tiram, kepiting saus tiram, dan lain-lain. Restoran Pondok Hijau juga menyedia makan perpaket yang dilengkapi, sayur kangkung dan nasih putih dan disempurnakan dengan bumbu-bumbu yang diambil dari bahanbahan pertanian. Dalam mendirikan suatu perusahaan bukanlah perkara yang mudah, namun memelihara dan mengembangkannya merupakan pekerjaan yang jauh lebih banyak tantangannya, sehingga para pengusaha dituntut untuk menentukan strategi pemasaran apa yang akan di gunakan dalam persaingan bisnis yang semakin ketat yang dapat memuaskan konsumen. Kualitas product merupakan senjata strategis yang potensial untuk mengalahkan pesaing, sehingga hanya perusahaan dengan mempunyai kualitas product yang paling baik akan tumbuh dengan pesat dan dalam jangka waktu yang panjang perusahaan tersebut akan berhasil dari perusahaan yang lain. Faktor-faktor lain yang mempengaruhi adalah faktor price dan place. Price yang di tentukan harus sesuai dengan kualitas product. place juga merupakan hal yang penting untuk menjadi pertimbangan konsumen. Faktor service, usaha yang bergerak di bidang ini sangat penting untuk memuaskan konsumen. Berkaitan dengan pentingnya tingkat kepuasan konsumen restoran pondok hijau, maka perlu diukur tingkat kepuasan konsumen pada rumah makan pondok hijau kota Manado, dimana dalam menjalankan strategi pemasaran rumah makan pondok hijau, maka perlu adanya bauran pemasaran yang meliputi: product, price, promotion, place, dan Service yang dapat dijadikan sebagai pedoman bagi Rumah Makan Pondok Hijau Kota Manado. Berdasarkan uraian latar belakang diatas, maka peneliti tertarik melakukan penelitian yang berjudul Tingkat Kepuasan Konsumen Pada Restoran Pondok Hijau Kota Manado.

\section{Rumusan Masalah}

Mengetahui tingkat kepuasan konsumen merupakan suatu hal yang sangat penting dan sangat dibutuhkan oleh suatu usaha dalam hal ini 
Restoran Pondok Hijau Kota Manado, terutama dalam meningkatkan usaha masyarakat yang dijalankan. Mengukur Tingkat Kepuasan Konsumen dapat mempengaruhi tingkat pendapatan Restoran Pondok Hijau Kota Manado. Berdasarkan latar belakang pemikiran di atas, maka dapatlah dirumuskan masalah yang akan dikaji dalam penelitian ini, yaitu: Bagaimana Tingkat Kepuasan Konsumen Restoran Pondok Hijau dilihat dari aspek product, price, place, promotion dan service?

\section{Tujuan dan Manfaat}

Tujuan dari penelitian ini adalah untuk mengukur tingkat kepuasan konsumen Restoran Pondok Hijau dilihat dari aspek product, price, place, promotion dan service.

\section{Manfaat Penelitian:}

1. Bagi peneliti dapat melatih cara berpikir serta menganalisis data, dan penelitian ini merupakan salah satu syarat untuk memperoleh gelar sarjana di fakultas pertanian universitas sam ratulangi manado.

2. Bagi pihak Restoran Pondok Hijau Kota Manado, diharapkan dapat menjadi bahan pertimbangan dalam menentukan product, price, place, promotion dan service dalam peningkatan usaha.

3. Bagi peneliti lain, dapat dijadikan referensi kajian dalam bidang penelitian serupa.

\section{METODOLOGI PENELITIAN}

\section{Waktu dan Tempat Penelitian}

Penelitian ini dilaksanakan selama tiga bulan dari bulan Februari sampai April 2017 yang dimulai dari persiapan sampai penyusunan laporan penelitian. Tempat penelitian adalah Restoran Pondok Hijau Kota Manado.

\section{Jenis-Jenis Data}

Adapun jenis data yang digunakan dalam penelitian ini adalah:

a. Data Primer

Data ini diperoleh secara langsung dari objek penelitian, yaitu data yang didapat dari konsumen restoran pondok hijau kota Manado melalui wawancara secara langsung dengan menggunakan daftar pernyataan (kuisioner) yang telah disiapkan. b. Data Sekunder

Data yang diperoleh dari buku-buku, jurnal penelitian dan literatur-literatur yang berkaitan dengan pembahasan permasalahan yang memiliki hubungan dengan penelitian ini.

\section{Metode Pengumpulan Data}

Untuk melengkapi hasil penelitian ini, maka penulis melakukan pengumpulan data dengan menggunakan:

1. Kuisioner: Teknik pengumpulan data dengan cara memberikan daftar pernyataan yang disebarkan pada konsumen Restoran Pondok Hijau kota Manado sebagai responden untuk diisi (menggunakan likert).

2. Wawancara: Dilakukan wawancaara kepada pimpinan dan Karyawan Restoran Pondok Hijau itu sendiri.

\section{Populasi dan Sampel}

Populasi adalah keseluruhan objek penelitian dimana populasi termasuk dalam populasi tak terhingga. Namun, populasi dapat diwakili oleh sebagian anggotanya yang disebut dengan sampel. Sampel adalah bagian dari jumlah data dan karakteristik yang dimiliki oleh populasi tersebut (Sugiyono, 2007 dalam Thesman dan Utama, 2010). Target populasi dalam penelitian ini adalah konsumen Restoran Pondok Hijau Kota Manado. Populasi nasabah dalam penelitian ini adalah seluruh (konsumen) yang menjadi pengunjung Restoran Pondok Hijau pada 3 bulan terakhir yang tercatat aktif berjumlah 3000 konsumen. Ukuran sampel konsumen Restoran Pondok Hijau ditentukan dengan menggunakan rumus Slovin (Consuelo dkk., 1993 dalam Yuliarmi dan Putu, 2007):

$$
\mathrm{n}=\frac{\mathrm{N}}{1+\mathrm{Ne}^{2}}=\frac{3000}{1+\left(3000 \mathrm{x} 0,1^{2}\right)}=96 \text { sampel }
$$

Keterangan :

$\mathrm{n}$ = Ukuran sampel

$\mathrm{N}=$ Ukuran populasi

$\mathrm{E}=$ Tingkat kesalahan yang ditoleransi, yaitu (10\%).

Teknik pengambilan sampel konsumen

Restoran Pondok Hijau menggunakan metode Accidental Sampling. Teknik penentuan sampel ini berdasarkan kebetulan, yaitu siapa saja yang secara kebetulan bertemu dengan peneliti yang dapat digunakan sebagai sampel, bila dipandang orang yang kebetulan ditemui cocok sebagai sumber data (Sujarweni, 2014). Sampel yang dimaksud yaitu konsumen yang membeli produk makanan baik 
makan di tempat dan yang beli bungkus. Kuesioner diberikan kepada konsumen setelah mengkonsumsi dan yang bersedia diwawancarai. Jumlah sampel sebanyak 96 orang/responden. Pengambilan dilakukan pada hari biasa dan hari libur dan mewawacarai langsung para konsumen yang secara kebetulan ada di Restoran Podok Hijau Kota Manado.

\section{Konsep Pengukuran Variabel}

Adapun yang terjadi konsep pengukuran variabel dalam penelitian ini adalah sebagai berikut :

1. Karakteristik Responden
a. Nama
b. Umur : Usia responden (tahun)
c. Jenis Kelamin : Laki-Laki / Perempuan
d. Tingkat Pendidikan : Lamanya responden menempuh pendidikan
e. Pekerjaan : Profesi dari responden saat diwawancara
f. Pendapatan per bulan : Gaji yang diterima reponden (Rp.)

2. Mengukur tingkat kepuasan konsumen yang diberikan oleh pihak rumah makan, adapun variabel-variabel yang diukur sebagai berikut :

2.1 Product. Product, berkaitan dengan kualitas dan kuantitas produk yang ditawarkan produsen. Indikator-indikatornya sebagai berikut :

a) Kebersihan dalam penyajian

b) Cita rasa produk

c) Tampilan fisik produk

2.2 Price. Price, berkaitan dengan jumlah uang yang dikeluarkan konsumen untuk memperoleh suatu product. Indikator-indikatornya sebagai berikut :

a) Terjangkau atau tidaknya price

b) Kesesuaian price dengan kuantitas/isi

c) Kesesuaian price dengan cita rasa

2.3Place. Place, berkaitan dengan fasilitas yang disediakan produsen. Indikator-indikatornya sebagai berikut :

a) Kebersihan Ruangan

b) Kenyamanan ruangan

c) Tampilan fisik Ruangan

d) Kelengkapan sarana dan fasilitas yang dimiliki

\subsection{Promotion}

a) Pengiklanan yang dilakukan Restoran Pondok Hijau b) Brosur yang disebarkan sangat membantu konsumen dalam mengetahui produkapa saja yang tersedia Restoran Pondok Hijau

c) Hubungan karyawan dan konsumen dalam mempromosikan produk berjalan dengan baik

2.5Service. Pelayanan berkaitan dengan pelayanan yang memuaskan kepada konsumen. Indikatorindikatornya sebagai berikut :

a) Keandalan jasa pelayanan (reliability), yaitu kecepatan dalam menyanjikan product yang dipesan.

b) Daya tanggap (responsiveness), yaitu kesigapan karyawan dalam memberikan service dalam menangani keluhan para konsumen Restoran Pondok Hijau.

c) Keyakinan (assurance), yaitu pengetahuan karyawan terhadap product yang dijual.

d) Kerapihan seragam dari karyawan dalam melayani konsumen

e) Empati (emphaty) yaitu, keramahan karyawan dalam melayani.

Variabel kepuasan konsumen diukur dengan menggunakan Skala Likert. Skala Likert (likert scale) adalah teknik pengukuran sikap yang paling luas digunakan dalam riset pemasaran. Dalam skala likert, maka variabel yang akan di ukur dijabarkan menjadi indikator variabel. Kemudian indikator tersebut dijadikan sebagai titik tolak untuk menyusun item-item instrument yang dapat berupa pernyataan-pernyataan. Dalam penelitian ini di susun 18 pernyataan dengan total responden 96 orang. Jawaban setiap instrument yang menggunakan skala likert, yang berupa katakata, antara lain :

$\mathrm{SP}=$ Sangat Puas

$\mathrm{P}=$ Puas

$\mathrm{N}=$ Netral

$\mathrm{TP}=$ Tidak Puas

STP $=$ Sangat Tidak Puas

Bila :

SP diberi skor $=5$

$\mathrm{P}$ diberi skor $=4$

$\mathrm{N}$ diberi skor $=3$

TP diberi skor $=2$

STP diberi skor $=1$

\section{Metode Analisis Data}

Dalam penelitian ini metode analisis data yang digunakan adalah analisis data deskriptif yaitu untuk menggambarkan dan mengukur Tingkat Kepuasan konsumen Restoran. Untuk mengetahui tentang Tingkat Kepuasan Konsumen 
Restoran Pondok Hijau Kota Manado, digunakan skala likert.

\section{Skala Likert}

Skala likert digunakan untuk mengukur sikap, pendapat dan persepsi seseorang atau kelompok orang tentang fenomena seseorang, Soegiyono dalam Sunyoto (2014). Dalam skala likert, maka variabel yang akan di ukur dijabarkan menjadi indikator variabel. Kemudian indikator tersebut dijadikan sebagai titik tolak untuk menyusun item-item instrument yang dapat berupa pernyataan-pernyataan 96 orang (konsumen). Jawaban setiap instrument yang menggunakan skala likert, yang berupa kata-kata, antara lain :

$$
\begin{array}{ll}
\text { SP } & =\text { Sangat Puas } \\
\text { P } & =\text { Puas } \\
\text { N } & =\text { Netral } \\
\text { TP } & =\text { Tidak Puas } \\
\text { STP } & =\text { Sangat Tidak Puas }
\end{array}
$$

Bila :

SP diberi skor $=5$

$\mathrm{P}$ diberi skor $=4$

$\mathrm{N}$ diberi skor $=3$

TP diberi skor $\quad=2$

STP diberi skor $=1$

Dengan cara perhitungan skor masingmasing penyataan: Jumlah skor tiap kriteria= capaian skor $\mathrm{X}$ jumlah responden.

$$
\begin{aligned}
& \mathrm{S} 5=5 \times 96=480 \\
& \mathrm{~S} 4=4 \times 96=384 \\
& \mathrm{~S} 3=3 \times 96=288 \\
& \mathrm{~S} 2=2 \times 96=192 \\
& \mathrm{~S} 1=1 \times 96=96
\end{aligned}
$$

Jumlah skor ideal untuk setiap pernyataan (skor tertinggi $)=480$. Jumlah skor terendah $=96$. Dengan interprestasi nilai: Cara perhitungan skor keseluruhan untuk mengetahui kepuasan konsumen: Jumlah skor seluruh kriterium= capaian jumlah skor $\mathrm{x}$ jumlah responden $\mathrm{x}$ instrumen pernyataan Untuk :

$\mathrm{S} 5=5 \times 96 \mathrm{X} 18=8640$

$\mathrm{S} 4=4 \times 96 \times 18=6912$

$\mathrm{S} 3=3 \times 96 \times 18=5184$

$\mathrm{S} 2=2 \times 96 \times 18=3456$

$\mathrm{S} 1=1 \mathrm{X} 96 \times 18=1728$

Jumlah skor ideal untuk keseluruhan pernyataan $=8640$ (tinggi). Jumlah skor terendah $=$ 1728 (rendah)

\section{Product}

$\mathrm{S} 5=5 \times 96 \times 3=1440$

$\mathrm{S} 4=4 \times 96 \times 3=1152$

$\mathrm{S} 3=3 \times 96 \times 3=864$

$\mathrm{S} 2=2 \times 96 \times 3=576$

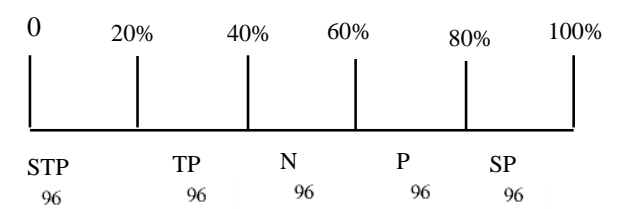

$\mathrm{S} 1=1 \times 96 \times 3=288$

Jumlah skor ideal untuk keseluruhan pernyataan $=1440$ (tinggi). Jumlah skor terendah= 288 (rendah)

\section{Price}

$\mathrm{S} 5=5 \times 96 \times 3=1440$

$\mathrm{S} 4=4 \times 96 \times 3=1152$

$\mathrm{S} 3=3 \times 96 \times 3=864$

$\mathrm{S} 2=2 \times 96 \times 3=576$

$\mathrm{S} 1=1 \times 96 \times 3=288$

Jumlah skor ideal untuk keseluruhan pernyataan $=1440$ (tinggi). Jumlah skor terendah $=$ 288 (rendah)

3. Place

$\mathrm{S} 5=5 \times 96 \times 4=1920$

$\mathrm{S} 4=4 \times 96 \times 4=1536$

$\mathrm{S} 3=3 \times 96 \times 4=1152$

$\mathrm{S} 2=2 \times 96 \times 4=768$

$\mathrm{S} 1=1 \times 96 \times 4=384$

Jumlah skor ideal untuk keseluruhan pernyataan $=1920$ (tinggi). Jumlah skor terendah= 384 (rendah)

4. Promotion

$\mathrm{S} 5=5 \times 96 \times 3=1440$

$\mathrm{S} 4=4 \times 96 \times 3=1152$

$\mathrm{S} 3=3 \times 96 \times 3=864$

$\mathrm{S} 2=2 \times 96 \times 3=576$

$\mathrm{S} 1=1 \times 96 \times 3=288$

Jumlah skor ideal untuk keseluruhan pernyataan $=1440$ (tinggi). Jumlah skor terendah= 288 (rendah)

5. Service

$\mathrm{S} 5=5 \times 96 \times 5=2400$

$\mathrm{S} 4=4 \times 96 \times 5=1920$

$\mathrm{S} 3=3 \times 96 \times 5=1440$

$\mathrm{S} 2=2 \times 96 \times 5=960$

$\mathrm{S} 1=1 \times 96 \times 5=480$

Jumlah skor ideal untuk keseluruhan pernyataan $=2400$ (tinggi). Jumlah skor terendah $=$ 480 (rendah)

\section{Analisis Indeks Kepuasan Konsumen}

Tingkat kepuasan konsumen $=\frac{\text { Jumlah Skor Hasil Pengumpulan Data }}{\text { Jumlah Skor Ideal (Tertinggi) }} \times 100 \%$

Dengan interprestasi nilai: Keterangan kriteria interpretasi skor kepuasan konsumen: 
Angka 0\% - 20\% = Sangat Tidak Puas

Angka 20\% - $40 \%=$ Tidak Puas

Angka $40 \%-60 \%=$ Netral

Angka 60\% - 80\% = Puas

Angka 80\% - 100\% = Sangat Puas

\section{HASIL DAN PEMBAHASAN}

\section{Deskripsi Umum Tempat Penelitian}

\section{Sejarah}

Restoran Pondok Hijau didirikan pada tanggal 14 Februari 2014, sehingga di Bulan Februari Tahun 2017 Pondok Hijau telah merayakan ulang tahun yang ketiga. Sebelum menjadi restoran seperti sekarang ini, Pondok Hijau merupakan area pemancingan ikan air tawar. Pada awal perkembangan manjadi restoran, Pondok Hijau membangun beberapa saung sebagai tempat untuk menikmati hidangan yang disediakan. Konsep yang ditawarkan di restoran ini ialah menikmati hidangan dan pemandangan alam yang asri. Pada area restoran dapat ditemui berbagai tanaman dengan bunga-bunga yang turut menambah keasrian taman yang mengelilingi area restoran. Berbagai pohon juga turut memperkuat kesan teduh di restoran ini. Restoran juga dilengkapi dengan fasilitas playground area dan golf driving area sehingga pengunjug yang membawa anak-anak dapat mengajak anak untuk bermain di area restoran atau kursus golf dengan pelatih-pelatih yang ada.

\section{Struktur Kepemimpinan}

Restoran Pondok Hijau merupakan usaha milik keluarga yang dikelolah secara profesional. Pemilik restoran yaitu Keluarga Karundeng-Pesoth yang mempercayakan pengelolaan restoran kepada Bapak John Pesoth (General Manager) dan Ibu Elly Sudjan Pesoth (Kitchen Manager) yang membawahi kurang lebih 60 orang tenaga kerja yang tersebar dalam beberapa divisi.

\section{Sistem Pemesanan}

Sistem pemesanana Restoran Pondok Hijau dilakukan secara langsung yaitu dengan melakukan pesanan saat tiba di restoran sedangkan pemesanan secara tidak langsung yaitu, dengan sistem reservasi melalui telepon. Untuk pesanan secara langsung, tamu dapat melakukan pemesanan kepada order taker. Selanjutnya order taker akan memasukan pesanan ke komputer sesuai dengan nomor meja. Pesanan kemudian akan diterima oleh Order Chequer dan disiapkan hingga akhirnya siap dibawah oleh Runner ke meja tamu. Penelitian ini bertujuan untuk mengetahui Kepuasan Konsumen Restoran Pondok Hijau Kota Manado ditinjau dari 5 Aspek yakni product, price, place, promotion dan service Dianalisis menggunakan pengukuran Likert Scale (Skala Likert).

\section{Karakteristik Responden}

Jumlah responden yang diambil dalam penelitian ini berjumlah 96 responden diambil dari 3000 konsumen restoran pondok hijau Manado. Penyajian data mengenai identitas responden disini, yaitu untuk memberikan gambaran tentang keadaan diri pada responden. Adapun gambaran tentang responden yang telah menjadi sampel dalam penelitian ini di klarifikasikan berdasarkan umur, pendidikan terakhir, jenis kelamin,, pekerjan utama dan pendapatan perbulan. Berikut ini akan dibahas mengenai kondisi dari masing - masing klasifikasi responden.

\section{Umur Konsumen}

Setiap konsumen restoran pondok hijau sudah pasti tidak sama, demikian juga dengan umur masing-masing konsumen, berikut adalah variasi umur dari tiap konsumen dapat di lihat pada Tabel 1.

Tabel 1. Umur Konsumen

\begin{tabular}{cccc}
\hline No & $\begin{array}{c}\text { Umur } \\
\text { (Tahun) }\end{array}$ & $\begin{array}{c}\text { Jumlah } \\
\text { Responden }\end{array}$ & $\begin{array}{c}\text { Persentasi } \\
(\%)\end{array}$ \\
\hline 1 & $21-30$ & 22 & 23 \\
2 & $31-40$ & 18 & 18 \\
3 & $41-50$ & 46 & 48 \\
4 & $51-60$ & 10 & 11 \\
& Jumlah & 96 & 100 \\
\hline
\end{tabular}

Sumber : Diolah dari data primer

Tabel 1 menunjukkan umur konsumen yang terbagi dari 4 bagian selanjutnya jumlah responden terbanyak pada umur dari 41-50 tahun dengan jumlah 46 konsumen dengan persentasi sebesar $48 \%$ sedangkan jumlah sampel dengan tingkatan umur terendah pada interval 51-60 
tahun dengan jumlah konsumen 10 dengan persentasi $11 \%$.

\section{Tingkat Pendidikan}

Tingkat pendidikan dari masing-masing orang berbeda, begitu juga dengan tingkat pendidikan dari masing-masing konsumen yang datang mengunjungi dan mengkonsumsi makanan di restoran pondok hijau kota Manado.

\section{Tabel 2. Tingkat Pendidikan Dari Konsumen}

\begin{tabular}{llcc}
\hline No & $\begin{array}{c}\text { Tingkat } \\
\text { Pendidikan }\end{array}$ & $\begin{array}{c}\text { Jumlah } \\
\text { Konsumen }\end{array}$ & Persentasi (\%) \\
\hline 1 & SMK & 2 & 2 \\
2 & SMA & 41 & 43 \\
3 & STM & 3 & 3 \\
4 & S1 & 40 & 42 \\
5 & S2 & 5 & 5 \\
6 & Dokter & 1 & 1 \\
7 & D3 & 2 & 2 \\
9 & Sekolah & 1 & 1 \\
& Pelayaran & & \\
& Jumlah & 96 & 100
\end{tabular}

Sumber : Diolah dari dari data primer

Tabel 2 menunjukkan jenjang pendidikan terakhir dari konsumen Restoran Pondok Hijau Kota Manado dan bahwa tingkat pendidikan responden yang terbanyak yaitu pada tingkatan SMA dengan jumlah 41 orang dengan persentasi $43 \%$. Sedangkan tingkat pendidikan responden yang paling sedikit dengan tingkat pendidikan dari 3 kategori yakni dokter Jumlah 1 orang dengan persentasi $1 \%$ dan sekolah pelayaran jumlah 1 orang dengan interpretasi $1 \%$.

\section{Jenis Kelamin}

Tabel 3. Jenis Kelamin Dari Konsumen Restoran Pomdok Kijau Kota Manado

\begin{tabular}{llcc}
\hline No & $\begin{array}{c}\text { Jenis } \\
\text { Kelamin }\end{array}$ & $\begin{array}{c}\text { Jumlah } \\
\text { Responden }\end{array}$ & Persentasi (\%) \\
\hline 1 & Laki-Laki & 60 & 62.5 \\
2 & Perempuan & 36 & 37.5 \\
& Jumlah & 96 & 100 \\
\hline
\end{tabular}

Sumber: Diolah dari data primer

Tabel 3 menunjukkan jenis kelamin. Sebagian besar responden konsumen restoran pondok hijau kota Manado adalah laki-laki dengan jumlah 60 dengan persentasi $62.5 \%$ sedangkan perempuan dengna jumlah 36 dengan interpretasi $37.5 \%$.

\section{Pekerjaan Utama}

Tabel 4 menunjukkan pekerjaan konsumen, bahwa pekerjaan utama responden yang terbanyak Dalam 3 bulan terakhir yaitu pada tingkatan PNS dengan jumlah 25 orang dengan persentasi $26 \%$. Sedangkan tingkat pekerjaan responden yang paling sedikit yakni Pelaut, Guru, Satpam, TNI-AD dan Pendeta dengan jumlah responden masing-masing 1 dan interpretasi $1 \%$.

Tabel 4. Jenis Pekerjaan Yakni Pekerjaan Utama Dari Konsumen Restoran Pondok Hijau Kota Manado

\begin{tabular}{llcc}
\hline No & $\begin{array}{c}\text { Pekerjaan } \\
\text { Utama }\end{array}$ & $\begin{array}{c}\text { Jumlah } \\
\text { Responden }\end{array}$ & $\begin{array}{c}\text { Persentasi } \\
(\%)\end{array}$ \\
\hline 1 & Polisi & 8 & 8 \\
2 & TNI- AU & 3 & 3 \\
3 & PNS & 25 & 26 \\
4 & Swasta & 16 & 17 \\
5 & Pensiunan PNS & 5 & 5 \\
6 & Mahasiswa & 2 & 2 \\
7 & Wirasuwasta & 8 & 8 \\
8 & Pengusaha & 13 & 14 \\
9 & Perawat & 5 & 5 \\
10 & Dokter & 2 & 2 \\
11 & Pelaut & 1 & 1 \\
12 & Guru & 1 & 1 \\
13 & Doden & 4 & 4 \\
14 & Satpam & 1 & 1 \\
15 & TNI - AD & 1 & 1 \\
16 & Pendeta & 1 & 1 \\
& Jumlah & 96 & 100 \\
\hline
\end{tabular}

Sumber: Diolah dari data primer

\section{Pendapatan Perbulan}

Tingkat pendapatan dari masing-masing orang berbeda, begitu juga dengan pendapatan dari masing-masing konsumen yang datang mengunjungi dan mengkonsumsi makanan di restoran Pondok Hijau Kota Manado.

Tabel 5 menunjukkan bahwa pendapatan perbulan responden yang terbanyak Dalam 3 bulan terakhir yaitu pada tingkatan $>5.000 .000$ jumlah responden 36 orang dan persentasi $37 \%$ dan jumlah responden yang paling sedikit dalam kaitannya dengan pendapatan perbulan dalam kategori $1.000 .000-2.000 .000$ yakni 5 orang dengna persentasi $5 \%$. 
Tabel 5. Pendapatan Dari Konsumen Restoran Pondok

\begin{tabular}{|c|c|c|c|c|}
\hline \multicolumn{5}{|c|}{ Hijau Kota Manado } \\
\hline No & $\begin{array}{c}\text { Pendapatan } \\
\text { perbulan }\end{array}$ & & $\begin{array}{c}\text { Jumlah } \\
\text { Responden }\end{array}$ & $\begin{array}{c}\text { Persentase } \\
(\%)\end{array}$ \\
\hline 1 & $<1.000 .000$ & & 3 & 3 \\
\hline 2 & $\begin{array}{l}1.000 .000 \\
2.000 .000\end{array}$ & - & 5 & 5 \\
\hline 3 & $\begin{array}{l}2.100 .000 \\
3.000 .000\end{array}$ & - & 18 & 19 \\
\hline 4 & $\begin{array}{l}3.100 .000 \\
4.000 .000\end{array}$ & - & 17 & 18 \\
\hline 5 & $\begin{array}{l}4.100 .000 \\
5.000 .000\end{array}$ & - & 17 & 18 \\
\hline 6 & $\begin{array}{l}>5.000 .000 \\
\text { Jumlah }\end{array}$ & & $\begin{array}{l}36 \\
96\end{array}$ & $\begin{array}{c}37 \\
100\end{array}$ \\
\hline
\end{tabular}

Sumber: Diolah dari data primer

\section{Mengukur Tingkat Kepuasan Konsumen Restoran Pondok Hijau Kota Manado}

Mengukur tingkat kepuasan konsumen sangat dibutuhkan oleh pihak yang terkait dalam hal ini restoran pondok hijau kota Manado tujuannya agara dapat mengetahui apa-apa kelibihan maupun kekurangan dari restoran tersebut agar restoran dapat maju dan mendapat keuntungan yang besar. Dalam hal ini tingkat kepuasan konsumen yang diukur adalah menggunakan 5 Aspek yakni: product, price, place, promotion dan Service. Pengukuran tingkat kepuasan konsumen restoran pondok hijau kota Manado yaitu sebanyak 96 responden terdiri dari 36 perempuan dan 60 laki-laki, yang rata-rata berusia antara 20-60 Tahun. Dengan tingkat pendidikan SMK 2 orang, $S M A=41$ orang, $S T M=$ 3 orang, $S 1=40$ orang, $S 2=5$ orang, Dokter $=1$, D3 $=2$ dan Sekolah Pelayaran $=1$.

\section{Product}

Product meliputi apa saja yang ditawarkan di restoran pondok hijau kota Manado. Pengkuran kepuasan konsumen dilihat dari kualitas product adalah untuk jenis usaha yang dikelolah Restoran Pondok Hijau Kota Manado.

\section{Kebersihan dalam penyajian}

Kebersihan disini merupakan bersih tidaknya restoran pondok hijau kota Manado. Tabel 6 menunjukkan bahwa kebersihan dalam penyajian makanan Restoran Pondok Hijau Kota Manado baik artinya bahwa kebersihan dalam penyajian produk restoran pondok hijau sesuai dengan kebutuhan konsumen. Angka indeks kepuasan konsumen mengenai kebersihan dalam penyajian yaitu : 425/480X100 $=88,54 \%$, sehingga interpretasinya tergolong Sangat Puas (SP).

\begin{tabular}{lcccc}
\multicolumn{5}{l}{ Tabel 6. Kebersihan dalam penyajian } \\
$\begin{array}{l}\text { Alternatif } \\
\text { Jawaban }\end{array}$ & $\begin{array}{c}\text { Alternatif } \\
\text { Skor }\end{array}$ & $\begin{array}{c}\text { Jumlah } \\
\text { Responden } \\
\text { (orang) }\end{array}$ & $\begin{array}{c}\text { Persentasi } \\
\text { Responden } \\
(\%)\end{array}$ & $\begin{array}{c}\text { Total } \\
\text { Skor }\end{array}$ \\
\hline Sangat & 5 & 55 & 57.29 & 220 \\
Puas & 4 & 41 & 42.70 & 205 \\
Puas & 3 & - & & - \\
Netral & 3 & - & & - \\
Tidak Puas & 2 & - & & - \\
Sangat & 1 & 96 & 100 & 425 \\
Tidak Puas & \multicolumn{5}{l}{} \\
Total & \multicolumn{5}{l}{} \\
\hline \multicolumn{5}{l}{ Sumber: Diolah dari data primer }
\end{tabular}

\section{Citra Rasa Product}

Citra rasa product yang dimaksud adalah kekhasan dan berkualitasnya cita rasa makanan yang ditawarkan dan dijual restoran pondok hijau kota Manado. Hasil penelitian ini menunjukkan bahwa cita rasa product makanan Restoran Pondok Hijau sesuai dengan kebutuhan konsumen. Angka indeks kepuasan konsumen mengenai kebersiahan dalam penyajian yaitu: $432 / 480 \times 100=90 \%$, sehingga interpretasinya tergolong Sangat Puas (SP).

\section{Tampilan Fisik Product}

Tampilan fisik product yang dimaksud adalah tampilan dari penyajian product yang sudah siap untuk dikonsumsi oleh konsumen restoran pondok hijau.

Tabel 7. Cita Rasa Product

\begin{tabular}{lllll}
$\begin{array}{c}\text { Alternatif } \\
\text { Jawaban }\end{array}$ & $\begin{array}{c}\text { Alternatif } \\
\text { Skor }\end{array}$ & $\begin{array}{c}\text { Jumlah } \\
\text { Responden } \\
\text { (Orang) }\end{array}$ & $\begin{array}{c}\text { Persentasi } \\
\text { Responden } \\
(\%)\end{array}$ & $\begin{array}{c}\text { Total } \\
\text { Skor }\end{array}$ \\
\hline $\begin{array}{l}\text { Sangat } \\
\text { Puas }\end{array}$ & 5 & 50 & 52.08 & 250 \\
Puas & 4 & 44 & 45.83 & 176 \\
Netral & 3 & 2 & 2.08 & 6 \\
Tidak & 2 & - & & - \\
Puas & & & & - \\
Sangat & 1 & - & & \\
Tidak & & & & 432 \\
Puas & & & 100 & \\
Total & & 96 & & \\
\hline
\end{tabular}

Sumber : Diolah dari data Primer

Hasil penelitian ini menunjukkan bahwa tampilan fisik product makanan restoran pondok hijau sesuai dengan kebutuhan konsumen. 
Angka indeks kepuasan konsumen mengenai kebersiahan dalam penyajian yaitu: $423 / 480 \times 100=88.12 \%, \quad$ sehingga interpretasinya tergolong Sangat Puas (SP).

Tabel 8. Tampilan fisik produk

\begin{tabular}{lccll}
$\begin{array}{c}\text { Alternatif } \\
\text { Jawaban }\end{array}$ & $\begin{array}{c}\text { Alternatif } \\
\text { Skor }\end{array}$ & $\begin{array}{c}\text { Jumlah } \\
\text { Responden } \\
\text { (Orang) }\end{array}$ & $\begin{array}{c}\text { Persentasi } \\
\text { Responden } \\
(\%)\end{array}$ & $\begin{array}{c}\text { Total } \\
\text { Skor }\end{array}$ \\
\hline $\begin{array}{l}\text { Sangat } \\
\text { Puas }\end{array}$ & 5 & 45 & 46.87 & 225 \\
Puas & 4 & 45 & 46.87 & 180 \\
Netral & 3 & 6 & 6.25 & 18 \\
Tidak & 2 & - & & - \\
$\begin{array}{l}\text { Puas } \\
\text { Sangat }\end{array}$ & 1 & - & & - \\
Tidak & & & & \\
Puas & & & 100 & 423 \\
Total & & 96 & & \\
\hline Sul
\end{tabular}

Sumber : Diolah dari data primer

\section{Pernyataan Product}

Pernyataan mengenai product yang ditawarkan dilihat dari total skor, indeks kepuasan kosumen dan interpretasi.

\section{Tabel 9. Pernyataan Product}

\begin{tabular}{ccccc}
\hline No & Pernyataan & $\begin{array}{l}\text { Total } \\
\text { Skor }\end{array}$ & $\begin{array}{c}\text { Indeks } \\
\text { kepuasan } \\
\text { konsumen }\end{array}$ & Interpretasi \\
\hline 1 & $\begin{array}{l}\text { Cita rasa } \\
\text { product }\end{array}$ & 432 & $90 \%$ & $\begin{array}{c}\text { Sangat } \\
\text { Puas }\end{array}$ \\
2 & $\begin{array}{l}\text { Kebersih } \\
\text { an dalam } \\
\text { penyajian }\end{array}$ & 425 & $88,54 \%$ & $\begin{array}{c}\text { Sangat } \\
\text { Puas }\end{array}$ \\
& $\begin{array}{l}\text { Tampilan } \\
\text { fisik } \\
\text { product }\end{array}$ & 423 & $88,12 \%$ & $\begin{array}{c}\text { Sangat } \\
\text { Puas }\end{array}$ \\
\hline
\end{tabular}

Sumber : Diolah dari data primer

Pernyataan tertinggi adalah cita rasa product dimana cita rasa menyangkut kualitasnya, kebersihan dalam penyajiannya baik, tampilan fisik product dapat membuat konsumen Restoran Pondok Hijau Kota Manado tertarik terhadap product yang ditawarkan dan interpretasi 3 pernyataan product tergolong Sangat Puas (SP).

\section{Price}

Price yang ada di Restoran Pondok hijau kota Manado. Pengkuran kepuasan konsumen dilihat dari price adalah untuk jenis usaha yang dikelolah oleh Restoran Pondok Hijau Kota Manado.

\section{Terjangkau Atau Tidaknya Price}

Biaya administrasi yang dimaksudkan disini merupakan biaya yang dikeluarkan konsumen.

Tabel 10. Terjangkau atau tidaknya Price

\begin{tabular}{lllll}
\hline $\begin{array}{c}\text { Alternatif } \\
\text { Jawaban }\end{array}$ & $\begin{array}{c}\text { Alternatif } \\
\text { Skor }\end{array}$ & $\begin{array}{c}\text { Jumlah } \\
\text { Responden } \\
\text { (Orang) }\end{array}$ & $\begin{array}{c}\text { Persentasi } \\
\text { Responden } \\
(\%)\end{array}$ & $\begin{array}{c}\text { Total } \\
\text { Skor }\end{array}$ \\
\hline $\begin{array}{l}\text { Sangat } \\
\text { Puas }\end{array}$ & 5 & 48 & 50 & 240 \\
Puas & 4 & 46 & 47.91 & 184 \\
Netral & 3 & 2 & 2.08 & 6 \\
Tidak & 2 & - & & - \\
Puas & & & & - \\
Sangat & 1 & - & & \\
Tidak & & & & \\
Puas & & & & \\
Total & & 96 & 100 & \\
\hline Sutal
\end{tabular}

Sumber : Diolah dari data primer

Hasil penelitian ini menunjukkan bahwa bahwa terjangkau atau tidaknya price Restoran Pondok Hijau Kota Manado, sesuai dengan keadaan konsumen. Angka indeks kepuasan konsumen mengenai kebersiahan dalam penyajian yaitu: $432 / 480 \times 100=90 \%$, sehingga interpretasinya tergolong Sangat Puas (SP).

\section{Kesesuaian Price Dengan Kuantitas/Isi}

Kesesuaian price yang dimaksud adalah kesesuaiannya dengan pendapatan konsumen Restoran Pondok Hijau Kota Manado.

\begin{tabular}{lcccc}
\multicolumn{5}{c}{ Tabel 11. Kesesuaian price dengan kuantitas/isi } \\
\hline $\begin{array}{l}\text { Alternatif } \\
\text { Jawaban }\end{array}$ & $\begin{array}{c}\text { Alternat } \\
\text { if Skor }\end{array}$ & $\begin{array}{c}\text { Jumlah } \\
\text { Responden } \\
\text { (Orang) }\end{array}$ & $\begin{array}{c}\text { Persentasi } \\
\text { Responden } \\
(\%)\end{array}$ & $\begin{array}{c}\text { Total } \\
\text { Skor }\end{array}$ \\
\hline $\begin{array}{l}\text { Sangat } \\
\text { Puas }\end{array}$ & 5 & 53 & 55.20 & 265 \\
Puas & 4 & 32 & 33.33 & 128 \\
Netral & 3 & 10 & 10.41 & 30 \\
Tidak & 2 & 1 & 1.04 & 2 \\
$\begin{array}{l}\text { Puas } \\
\text { Sangat }\end{array}$ & 1 & - & & - \\
Tidak & & & & \\
Puas & & & & \\
Total & & 96 & 100 & 425 \\
\hline
\end{tabular}

Sumber : Diolah dari data primer

Hasil penelitian ini menunjukkan bahwa kesesuaian price dengan kuantitas/isi product Restoran Pondok Hijau Kota Manado sesuai dengan keadaan konsumen. Angka indeks kepuasan konsumen mengenai kesesuaian dari 
price dengan kuantitas/isi yaitu : 425/480X100 $=88.54 \%$, sehingga interpretasinya tergolong Sangat Puas (SP).

\section{Kesesuaian Price Dengan Cita Rasa}

Kesesuaian price harus sesuai dengan cita rasa agar konsumen dapat merasa puas dengan product yang ditawarkan.

Tabel 12. Kesesuaian price dengan cita rasa

\begin{tabular}{lcccc}
\hline $\begin{array}{l}\text { Alternatif } \\
\text { Jawaban }\end{array}$ & $\begin{array}{c}\text { Alternati } \\
\text { f Skor }\end{array}$ & $\begin{array}{c}\text { Jumlah } \\
\text { Responden } \\
\text { (Orang) }\end{array}$ & $\begin{array}{c}\text { Persentasi } \\
\text { Responden } \\
(\%)\end{array}$ & $\begin{array}{c}\text { Total } \\
\text { Skor }\end{array}$ \\
\hline $\begin{array}{l}\text { Sangat } \\
\text { Puas }\end{array}$ & 5 & 43 & 44.79 & 215 \\
Puas & 4 & 47 & 48.95 & 188 \\
Netral & 3 & 6 & 6.25 & 18 \\
Tidak & 2 & - & & \\
Puas & & & & - \\
Sangat & 1 & - & & \\
Tidak & & & 100 & 421 \\
Puas & & & & \\
Total & & 96 & &
\end{tabular}

Sumber: Diolah dari data primer

Hasil penelitian ini menunjukkan bahwa kesesuaian price dengan cita rasa Restoran Pondok Hijau sesuai dengan keadaan konsumen. Angka indeks kepuasan konsumen mengenai kesesuaian dari price dengan cita rasa yaitu : 421/480X100 $=87.70 \%$, sehingga interpretasinya tergolong Sangat Puas (SP).

\section{Pernyataan Price}

Pernyataan, total skor, indeks kepuasan dan interpretasi nilai.

Tabel 13. Tabel 13. Pernyataan Price

\begin{tabular}{ccccc}
\hline No & Pernyataan & $\begin{array}{c}\text { Total } \\
\text { Skor }\end{array}$ & $\begin{array}{c}\text { Indeks } \\
\text { Kepuasaan } \\
\text { Konsumen }\end{array}$ & Interpretasi \\
\hline $1 \quad \begin{array}{l}\text { Terjangkau } \\
\text { atau } \\
\text { tidaknya }\end{array}$ & 432 & $90 \%$ & $\begin{array}{c}\text { Sangat } \\
\text { Puas }\end{array}$ \\
\hline $\begin{array}{l}\text { Price } \\
\text { Kesesuaian } \\
\text { price } \\
\text { dengan } \\
\text { kuantitas/isi } \\
\text { Kesesuaian } \\
\text { price } \\
\text { dengan cita } \\
\text { rasa }\end{array}$ & 425 & $88,54 \%$ & $\begin{array}{c}\text { Sangat } \\
\text { Puas }\end{array}$ \\
\hline $\begin{array}{l}\text { Sumber : Diolah dari data primer } \\
\text { Sesuai dengan hasil yang }\end{array}$ & didapat \\
\hline
\end{tabular}
pernyataan tertinggi adalah terjangkau atau tidaknya price berarti dapat dijangkau oleh konsumen. Kesesuaian price dengan kuantitas/isi juga sepadan atau dapat dikatakan baik. Kesesuaian price dengan cita rasa baik. Sehingga interpretasi tergolong Sangat Puas (SP).

\section{Place}

Place sangat mempengaruhi pemasaran suatu product. kaitannya disini adalah tempat Restoran Pondok Hijau Kota Manado yang memasarkan product mereka.

\section{Kebersihan Ruangan}

Tempat yang bersih atau ruangan yang bersih dapat membuat konsumen merasa nyaman berada disana.

\begin{tabular}{|c|c|c|c|c|}
\hline $\begin{array}{c}\text { Alternatif } \\
\text { Jawaban }\end{array}$ & $\begin{array}{l}\text { Alternatif } \\
\text { Skor }\end{array}$ & $\begin{array}{c}\text { Jumlah } \\
\text { Responden } \\
\text { (Orang) }\end{array}$ & $\begin{array}{c}\text { Persentasi } \\
\text { Responden } \\
(\%)\end{array}$ & $\begin{array}{l}\text { Total } \\
\text { Skor }\end{array}$ \\
\hline $\begin{array}{l}\text { Sangat } \\
\text { Puas }\end{array}$ & 5 & 45 & 46.87 & 225 \\
\hline Puas & 4 & 49 & 51.04 & 196 \\
\hline Netral & 3 & 2 & 2.08 & 6 \\
\hline $\begin{array}{l}\text { Tidak } \\
\text { Puas }\end{array}$ & 2 & - & & \\
\hline $\begin{array}{l}\text { Sangat } \\
\text { Tidak } \\
\text { Puas }\end{array}$ & 1 & - & & - \\
\hline Total & & 96 & 100 & 427 \\
\hline
\end{tabular}

Hasil penelitian ini menunjukkan bahwa ruangan Restoran Pondok hijau Kota Manado baik. Angka indeks kepuasan konsumen mengenai kebersihan ruangan yaitu : 427/480X100 $=88.95 \%$, sehingga interpretasinya tergolong Sangat Puas (SP).

\section{Kenyamanan Ruangan}

Nyaman berarti konsumen merasa baik berada di Restoran Pondok Hijau Kota Manado.

\begin{tabular}{lcccc}
\multicolumn{5}{l}{ Tabel 15. Kenyamanan ruangan } \\
\hline $\begin{array}{l}\text { Alternatif } \\
\text { Jawaban }\end{array}$ & $\begin{array}{c}\text { Alternatif } \\
\text { Skor }\end{array}$ & $\begin{array}{c}\text { Jumlah } \\
\text { Responden } \\
\text { (Orang) }\end{array}$ & $\begin{array}{c}\text { Persentasi } \\
\text { Responden } \\
(\%)\end{array}$ & $\begin{array}{c}\text { Total } \\
\text { Skor }\end{array}$ \\
\hline Sangat & 5 & 47 & 48.95 & 235 \\
Puas & 4 & 42 & 43.75 & 168 \\
Puas & 3 & 6 & 6.25 & 18 \\
Netral & 2 & 1 & 1.04 & 2 \\
Tidak & 1 & - & & - \\
$\begin{array}{l}\text { Puas } \\
\text { Sangat }\end{array}$ & 1 & & & \\
Tidak & & & & \\
Puas & & 96 & 100 & 423 \\
Total & & &
\end{tabular}


Hasil penelitian ini menunjukkan bahwa artinya kenyaman ruangan restoran pondok hijau baik. Angka indeks kepuasan konsumen mengenai kenyamanan ruangan yaitu: 423/480X100=88.12\%, Sehingga interpretasinya tergolong Sangat Puas (SP).

\section{Tampilan Fisik Ruangan}

Tampilan fisik restoran mempengaruhi konsumen yang datang mengunjungi Restoran Pondok Hijau Kota Manado.

Tabel 16. Tampilan fisik ruangan

\begin{tabular}{lcccc}
\hline $\begin{array}{c}\text { Alternatif } \\
\text { Jawaban }\end{array}$ & $\begin{array}{c}\text { Alternatif } \\
\text { Skor }\end{array}$ & $\begin{array}{c}\text { Jumlah } \\
\text { Responden } \\
\text { (Orang) }\end{array}$ & $\begin{array}{c}\text { Persentasi } \\
\text { Responden } \\
(\%)\end{array}$ & $\begin{array}{c}\text { Total } \\
\text { Skor }\end{array}$ \\
\hline $\begin{array}{l}\text { Sangat } \\
\text { Puas }\end{array}$ & 5 & 49 & 51.04 & 245 \\
$\begin{array}{l}\text { Puas } \\
\text { Netral }\end{array}$ & 4 & 42 & 43.75 & 168 \\
Tidak & 2 & 4 & 4.16 & 12 \\
$\begin{array}{l}\text { Puas } \\
\text { Sangat } \\
\text { Tidak }\end{array}$ & 1 & - & & - \\
$\begin{array}{l}\text { Puas } \\
\text { Total }\end{array}$ & & 1 & 1.04 & 1 \\
\hline \multicolumn{5}{l}{ Sumber : Diolah dari data primer } \\
\end{tabular}

Hasil penelitian ini menunjukkan bahwa tampilan fisik tempat atau ruangannya baik karena tempatnya strategis dapat menyatu dengan alam artinya banyak pepohonan, terdapat pondok-pondok dan konsumen pun dapat melihat dan memberikan makanan pada ikan-ikan yang ada disana. Angka indeks kepuasan konsumen mengenai tampilan fisik ruangan yaitu: $426 / 480 \times 100=88.75 \%$, sehingga interpretasinya tergolong Sangat Puas (SP).

\section{Kelengkapan Sarana Dan Fasilitas Yang Dimiliki}

Kelengkapan sarana dan fasilitas yang dimiliki dimaksud disini adalah tersedianya sarana penunjang seperti Wifi, Bel untuk memanggil pelayan yang tujuannya untuk memesan makanan, tempat yang menarik karena dilengkapi dengan lapangan golf dan lain sebagainya.

\begin{tabular}{lcccc}
\multicolumn{5}{c}{ Tabel 17. Kelengkapan sarana dan fasilitas yang dimiliki } \\
\hline $\begin{array}{l}\text { Alternatif } \\
\text { Jawaban }\end{array}$ & $\begin{array}{c}\text { Alternatif } \\
\text { Skor }\end{array}$ & $\begin{array}{c}\text { Jumlah } \\
\text { Responden } \\
\text { (Orang) }\end{array}$ & $\begin{array}{c}\text { Persentasi } \\
\text { Responden } \\
(\%)\end{array}$ & $\begin{array}{c}\text { Total } \\
\text { Skor }\end{array}$ \\
\hline $\begin{array}{l}\text { Sangat } \\
\text { Puas }\end{array}$ & 5 & 54 & 56.25 & 270 \\
Puas & 4 & 35 & 36.45 & 140 \\
Netral & 3 & 6 & 6.25 & 18 \\
Tidak & 2 & 1 & 1.04 & 2 \\
$\begin{array}{l}\text { Puas } \\
\text { Sangat }\end{array}$ & 1 & - & - & - \\
Tidak & & & & \\
$\begin{array}{l}\text { Puas } \\
\text { Total }\end{array}$ & & 96 & 100 & 430 \\
\hline
\end{tabular}

Sumber : Diolah dari data primer

Hasil penelitian ini menunjukkan bahwa artinya kelengkapan sarana dan fasilitas Restoran Pondok Hijau Kota Manado baik dan lengkap seperti yang dijelaskan diatas banyak terdapat penunjang sarana-sarana yang dapat membuat konsumen merasa nyaman berada disana. Angka indeks kepuasan konsumen mengenai kelengkapan sarana dan fasilitas yaitu: $430 / 480 \times 100=89.58 \%$, sehingga interpretasinya tergolong Sangat Puas (SP).

\section{Pernyataan Place}

Pernyataan mengenai place dari product yang ditawarkan dengan total skor, indeks kepuasan dan interpretasi nilai.

\begin{tabular}{ccccc}
\multicolumn{2}{l}{ Tabel 18. Pernyataan Place } & & \\
\hline No & Pernyataan & $\begin{array}{c}\text { Total } \\
\text { Skor }\end{array}$ & $\begin{array}{c}\text { Indeks } \\
\text { Kepuasaan } \\
\text { Konsumen }\end{array}$ & [nterpretasi \\
\hline 1 & $\begin{array}{l}\text { Kelengkapan } \\
\text { sarana dan } \\
\text { fasilitas yang } \\
\text { dimiliki }\end{array}$ & 430 & $89,58 \%$ & $\begin{array}{c}\text { Sangat } \\
\text { Puas }\end{array}$ \\
2 & $\begin{array}{l}\text { Kebersihan } \\
\text { ruangan } \\
\text { Tampilan }\end{array}$ & 427 & $88.95 \%$ & $\begin{array}{c}\text { Sangat } \\
\text { Puas } \\
\text { fisik ruangan } \\
\text { Kenyamanan } \\
\text { Puas }\end{array}$ \\
\hline & 426 & $88.75 \%$ & $\begin{array}{c}\text { Sangat } \\
\text { Puas }\end{array}$ \\
\hline
\end{tabular}

Sumber : Diolah dari data primer

Sesuai dengan hasil yang didapat pernyataan tertinggi adalah kelengkapan sarana dan fasilitas yang dimiliki indeks kepuasan konsumen karena ditunjang dengan saranasarana penunjang yang sangat baik seperti (bel, 
wifi dan lapangan golf). Tampilan fisik ruangan indeks kepuasan konsumen baik karena terdapat juga pondok-pondok. Kebersihan ruangan baik karena kebersihan pula menyangkut daya tarik dari konsumen. Kenyamanan ruangan di Restoran Pondok Hijau Kota Manado dapat membuat konsumen selalu ingin mengunjungi restoran ini, sehingga interpretasi tergolong Sangat Puas (SP).

\section{Promotion}

Promotion terdiri dari 2 cara yang Restoran Pondok Hijau Kota Manado terapkan yaitu promotion secara langsung (membagikan brosur-brosur makanan secara langsung kepada calon konsumen yang berkunjung disana dan menjelaskan menu-menu unggulan yang bersada disana) dan promotion secara tidak langsung (internet, media masa dan memasang spandukspanduk/banners dan bekerja sama dengan pihak-pihak yang lain).

\section{Pengiklanan Yang Dilakukan Restoran Pondok Hijau \\ Pengiklananan (internet) yang dilakukan} restoran pondok hijau kota Manado dapat membantu konsumen agar mudah menemukan dan mendapatkan informasi tentang restoran pondok hijau kota Manado.

Tabel 19. Pengiklanan yang dilakukan restoran pondok

\begin{tabular}{|c|c|c|c|c|}
\hline $\begin{array}{c}\text { Alternatif } \\
\text { Jawaban }\end{array}$ & $\begin{array}{l}\text { Alternatif } \\
\text { Skor }\end{array}$ & $\begin{array}{c}\text { Jumlah } \\
\text { Responden } \\
\text { (Orang) }\end{array}$ & $\begin{array}{c}\text { Persentasi } \\
\text { Responden } \\
(\%)\end{array}$ & $\begin{array}{l}\text { Tota } \\
\text { Skor }\end{array}$ \\
\hline $\begin{array}{l}\text { Sangat } \\
\text { Puas }\end{array}$ & 5 & 47 & 48.95 & 235 \\
\hline Puas & 4 & 43 & 44.79 & 172 \\
\hline Netral & 3 & 6 & 6.25 & 18 \\
\hline $\begin{array}{l}\text { Tidak } \\
\text { Puas }\end{array}$ & 2 & - & - & - \\
\hline $\begin{array}{l}\text { Sangat } \\
\text { Tidak } \\
\text { Puas }\end{array}$ & 1 & - & 100 & - \\
\hline Total & & 96 & 100 & 425 \\
\hline
\end{tabular}

Sumber :Diolah dari data primer

Hasil penelitian ini menunjukkan bahwa Pengiklanan yang dilakukan resoran pondok hijau baik karena bisa bekerja sama dengan citylink dan bisa dilihat dari internet. Angka indeks kepuasan konsumen mengenai Pengiklanan yang dilakukan resoran pondok hijau yaitu : 425/480X100 $=88.54 \%$, sehingga interpretasinya tergolong Sangat Puas (SP).

Brosur Yang Disebarkan Sangat Membantu Konsumen Dalam Mengetahui Produk Apa Saja Yang Tersedia Di Restoran Pondok Hijau Kota Manado

Brosur yang di sebarkan oleh pihak restoran memang sangat membantu bagi para konsumen untuk mengetahui informasi tentang makanan yang ditawarkan disana. Brosur yang dimaksud disini adalah brosur makanan yang ditawarkan dan makanan-makanan unggulan yang mereka tawarkan kepada konsumen.

Tabel 20. Brosur yang disebarkan sangat membantu konsumen dalam mengetahui produk apa saja yang tersedia di Restoran Pondok Hijau Kota Manado

\begin{tabular}{lllll}
\hline $\begin{array}{c}\text { Alternatif } \\
\text { Jawaban }\end{array}$ & $\begin{array}{c}\text { Alternatif } \\
\text { Skor }\end{array}$ & $\begin{array}{c}\text { Jumlah } \\
\text { Responden } \\
\text { (Orang) }\end{array}$ & $\begin{array}{c}\text { Persentasi } \\
\text { Responden } \\
(\%)\end{array}$ & $\begin{array}{c}\text { Total } \\
\text { Skor }\end{array}$ \\
\hline Sangat Puas & 5 & 57 & 59.37 & 285 \\
Puas & 4 & 32 & 33.33 & 128 \\
Netral & 3 & 5 & 5.20 & 15 \\
Tidak Puas & 2 & 2 & 2.08 & 4 \\
Sangat Tidak & 1 & - & - & - \\
Puas & & & \\
Total & 96 & 100 & 432 \\
\hline Sumber : Diolah dari data primer
\end{tabular}

Hasil penelitian ini menunjukkan bahwa cara penyampaian produk-produk unggulan dalam brosur makanan yang dilakukan Restoran Pondok Hijau Kota Manado baik. Angka indeks kepuasan konsumen mengenai cara penyampaian yang dilakukan resoran pondok hijau yaitu: $432 / 480 \times 100=90 \%$, sehingga interpretasinya tergolong Sangat Puas (SP).

Hubungan karyawan dan konsumen dalam mempromosikan product berjalan dengan baik

Terjalinnya kerjasama yang baik itu dari konsumen dan dari karyawan. Agar suasana yang baik dalam hal mempromosikan suatu product yang ditawarkan disana.

Hasil penelitian ini menunjukkan bahwa hubungan karyawan dan konsumen dalam mempromosikan product berjalan dengan baik karena karyawan mampu membuat konsumen selalu berkujung disana. Angka indeks kepuasan konsumen mengenai hubungan karyawan dan konsumen dalam mempromosikan product berjalan dengan baik yaitu: 428/480X100= 
$89.16 \%$, sehingga interpretasinya tergolong Sangat Puas (SP).

Tabel 21. Hubungan karyawan dan konsumen dalam mempromosikan product berjalan dengan baik

\begin{tabular}{|c|c|c|c|c|}
\hline $\begin{array}{l}\text { Alternatif } \\
\text { Jawaban }\end{array}$ & $\begin{array}{c}\text { Alternatif } \\
\text { Skor }\end{array}$ & $\begin{array}{c}\text { Jumlah } \\
\text { Responden } \\
\text { (Orang) }\end{array}$ & $\begin{array}{c}\text { Persentasi } \\
\text { Responden } \\
(\%)\end{array}$ & $\begin{array}{l}\text { Total } \\
\text { Skor }\end{array}$ \\
\hline $\begin{array}{l}\text { Sangat } \\
\text { Puas }\end{array}$ & 5 & 51 & 53.12 & 255 \\
\hline Puas & 4 & 38 & 39.58 & 152 \\
\hline Netral & 3 & 7 & 7.29 & 21 \\
\hline Tidak Puas & 2 & - & - & - \\
\hline $\begin{array}{l}\text { Sangat } \\
\text { Tidak Puas }\end{array}$ & 1 & - & - & - \\
\hline Total & & 96 & 100 & 428 \\
\hline
\end{tabular}

\section{Pernyataan Promotion}

Cara mempromosikan product sangat berpengaruh dapat dilihat dari total skor, indeks kepuasan konsumen dan interpretasi nilai.

\begin{tabular}{|c|c|c|c|c|}
\hline No & Pernyataan & $\begin{array}{l}\text { Total } \\
\text { Skor }\end{array}$ & $\begin{array}{c}\text { Indeks } \\
\text { Kepuasan } \\
\text { Konsumen }\end{array}$ & Interpretasi \\
\hline 1 & $\begin{array}{l}\text { Brosur yang } \\
\text { disebarkan } \\
\text { sangat } \\
\text { membantu } \\
\text { konsumen dalam } \\
\text { mengetahui } \\
\text { produk apa saja } \\
\text { yang tersedia di } \\
\text { restoran pondok } \\
\text { hijau kota } \\
\text { manado }\end{array}$ & 432 & $90 \%$ & $\begin{array}{c}\text { Sangat } \\
\text { Puas }\end{array}$ \\
\hline 2 & $\begin{array}{l}\text { Hubungan } \\
\text { karyawan dan } \\
\text { konsumen dalam } \\
\text { mempromosikan } \\
\text { produk berjalan } \\
\text { dengan baik }\end{array}$ & 428 & $89.16 \%$ & $\begin{array}{c}\text { Sangat } \\
\text { Puas }\end{array}$ \\
\hline 3 & $\begin{array}{l}\text { Pengiklanan } \\
\text { yang dilakukan } \\
\text { restoran Pondok } \\
\text { Hijau }\end{array}$ & 425 & $88.54 \%$ & $\begin{array}{c}\text { Sangat } \\
\text { Puas }\end{array}$ \\
\hline
\end{tabular}

Sesuai dengan hasil penelitian yang didapat dari 3 pernyataan. Pernyataan tertinggi adalah Brosur yang disebarkan sangat membantu konsumen dalam mengetahui produk apa saja yang tersedia di restoran pondok hijau kota manado (karyawan mampu membuat yakin konsumen dalam hal product unggulan Restoran
Pondok Hijau Kota Manado). hubungan karyawan dan konsumen dalam mempromosikan product berjalan dengan baik dalam hal kepercayaan konsumen. Pengiklanan yang dilakukan restoran Pondok Hijau disini pengiklanan di internet dan sudah bekerjasama dengan citylink.

\section{Service}

Proses makanan yang disediakan mulai dari Input menjadi Output. Apakah menemui kendala atau belum/tidak.

\section{Kecepatan dalam menyajikan product yang dipesan}

Kecepatan dalam menyajikan product yang dipesan oleh konsumen merupakan syarat utama dari konsumen kepada karyawan restoran pondok hijau kota Manado.

Tabel 23. Kecepatan dalam menyajikan product yang dipesan

\begin{tabular}{lcccc}
\hline $\begin{array}{l}\text { Alternatif } \\
\text { Jawaban }\end{array}$ & $\begin{array}{c}\text { Alternatif } \\
\text { Skor }\end{array}$ & $\begin{array}{c}\text { Jumlah } \\
\text { Responden } \\
\text { (Orang) }\end{array}$ & $\begin{array}{c}\text { Persentasi } \\
\text { Responden } \\
(\%)\end{array}$ & $\begin{array}{c}\text { Total } \\
\text { Skor }\end{array}$ \\
\hline Sangat & 5 & - & - & - \\
Puas & & 4 & 4.16 & 16 \\
Puas & 4 & 31 & 32.29 & 93 \\
Netral & 3 & 54 & 56.25 & 108 \\
Cukup & 2 & 7 & 7.29 & 7 \\
$\begin{array}{l}\text { Puas } \\
\text { Sangat }\end{array}$ & 1 & & & \\
Tidak & & 96 & 100 & 224 \\
$\begin{array}{l}\text { Puas } \\
\text { Total }\end{array}$ & & & & \\
\hline Sumber : Diolah dari data primer & & &
\end{tabular}

Hasil penelitian ini, menyangkut kecepatan dalam menyajikan product yang dipesan menurut konsumen tidak terlalu baik alasannya dalam penyajian makanan memerlukan waktu yang lama dan membuat konsumen merasa kurang nyaman. Angka indeks kepuasan konsumen mengenai kecepatan dalam menyajikan product yang dipesan yang dilakukan Restoran Pondok Hijau yaitu : $224 / 480 \times 100=46.66 \%$, sehingga interpretasinya tergolong Netral $(\mathrm{N})$. 
Kesigapan karyawan dalam memberikan pelayanan dalam menangani keluhan para konsumen Restoran Pondok Hijau.

Kesigapan atau kecepatan yang dimaksud disini kesigapan yang dilakukan oleh karyawan dalam melayani konsumen.

Tabel 24. Kesigapan karyawan dalam memberikan pelayanan dalam menangani keluhan para konsumen Restoran Pondok Hijau

\begin{tabular}{lcccc}
\hline $\begin{array}{l}\text { Alternatif } \\
\text { Jawaban }\end{array}$ & $\begin{array}{c}\text { Alternatif } \\
\text { Skor }\end{array}$ & $\begin{array}{c}\text { Jumlah } \\
\text { Responden } \\
\text { (Orang) }\end{array}$ & $\begin{array}{c}\text { Persentasi } \\
\text { Responden } \\
(\%)\end{array}$ & $\begin{array}{c}\text { Total } \\
\text { Skor }\end{array}$ \\
\hline Sangat & 5 & - & - & - \\
Puas & & & & \\
Puas & 4 & 3 & 3.12 & 12 \\
Netral & 3 & 23 & 23.95 & 69 \\
Tidak & 2 & 63 & 65.62 & 126 \\
Puas & 1 & 7 & 7.29 & 7 \\
Sangat & & & & \\
Tidak & & & & \\
Puas & & 96 & 100 & 214 \\
Total & & & &
\end{tabular}

Sumber : Diolah dari data primer

Hasil penelitian ini, konsumen menilai kurang baik artinya karyawan kurang sigap dalam melayani konsumen dan mungkin perlu diberikan pelatihan kepada karyawan Restoran Pondok Hijau Kota Manado. Angka indeks kepuasan konsumen yaitu : 214/480X100= $44.58 \%$, sehingga interpretasinya tergolong Netral (N).

\section{Pengetahuan karyawan terhadap product yang dijual}

Bicara mengetahui pengetahuan, hal ini diperlukan karyawan maksudnya pengetahuan mengenai product yang ditawarkan.

Tabel 25. Pengetahuan karyawan terhadap product yang

\begin{tabular}{lllll}
\multicolumn{2}{c}{ dijual } & & & \\
\hline Alternatif & Alternatif & Jumlah & Persentasi & Total \\
Jawaban & Skor & $\begin{array}{l}\text { Responden } \\
\text { (Orang) }\end{array}$ & $\begin{array}{l}\text { Responden } \\
(\%)\end{array}$ & Skor \\
\hline
\end{tabular}

$\begin{array}{lllll}\text { Sangat } & 5 & - & - & - \\ \text { Puas } & & & & \\ \text { Puas } & 4 & 3 & 3.12 & 12 \\ \text { Netral } & 3 & 21 & 21.87 & 63 \\ \text { Tidak Puas } & 2 & 67 & 69.79 & 134 \\ \begin{array}{l}\text { Sangat } \\ \text { Tidak Puas }\end{array} & 1 & 5 & 5.20 & 5 \\ \begin{array}{l}\text { Total } \\ \text { Sumber : Diolah dari data primer }\end{array} & & \\ \end{array}$

Hasil penelitian ini, menrut penilaian yang didapat dari konsumen mengenai pengetahuan karyawan terhadap product yang dijual kurang dan itu dapat menjadi perhatian pada pemimpin Restoran Pondok Hijau Kota Manado. Angka indeks kepuasan yaitu: $214 / 480 \times 100=\quad 44.58 \%, \quad$ sehingga interpretasinya tergolong $\operatorname{Netral}(\mathrm{N})$.

\section{Kerapihan seragam dari karyawan dalam melayani konsumen}

Kerapihan seragam dari karyawan dapat membuat nilai tambahan dari para konsumen dalam menilai bagaimanan cara berpakaian dari karyawan restoran pondok hijau kota Manado.

Tabel 26. Kerapihan seragam dari karyawan dalam melayani konsumen

\begin{tabular}{lcccc}
\multicolumn{5}{c}{ melayani konsumen } \\
$\begin{array}{l}\text { Alternatif } \\
\text { Jawaban }\end{array}$ & $\begin{array}{c}\text { Alternatif } \\
\text { Skor }\end{array}$ & $\begin{array}{c}\text { Jumlah } \\
\text { Responden } \\
\text { (Orang) }\end{array}$ & $\begin{array}{c}\text { Persentasi } \\
\text { Responden } \\
(\%)\end{array}$ & $\begin{array}{c}\text { Total } \\
\text { Skor }\end{array}$ \\
\hline Sangat & 5 & - & - & - \\
Puas & & & & \\
Puas & 4 & 2 & 2.08 & 8 \\
Netral & 3 & 22 & 22.91 & 66 \\
Tidak & 2 & 64 & 66.66 & 128 \\
Puas & & & & \\
Sangat & 1 & 8 & 8.33 & 8 \\
Tidak & & & & \\
Puas & & & & \\
Total & & 96 & 100 & 210 \\
\hline Sual
\end{tabular}

Sumber : Diolah dari data primer

Hasil penelitian ini, menurut penilaian konsumen kayawan kurang rapih dalam melayani konsumen. Angka indeks kepuasan konsumen mengenai kecepatan dalam menyajikan produk yang dipesan yang dilakukan resoran pondok hijau yaitu : 210/480X100 $=43.75 \%$, sehingga interpretasinya tergolong Netral $(\mathrm{N})$.

\section{Keramahan Karyawan Dalam Melayani}

Ramah berarti sopan, karyawan yang ramah merupakan karyawan yang diharapkan oleh konsumen.

Hasil penelitian ini, keramahannya berada pada posisi netral kareana ada karyawan yang kurang memperlihatkan keramahannya dalam hal berbicara dan raut wajahnya. Angka indeks kepuasan konsumen mengenai Keramahan karyawan dalam melayani yaitu : $211 / 480 \times 100=\quad 43.95 \%, \quad$ sehingga interpretasinya tergolong Netral $(\mathrm{N})$. 
Tabel. 27 Keramahan karyawan dalam melayani

\begin{tabular}{lcccl}
\hline $\begin{array}{c}\text { Alternatif } \\
\text { Jawaban }\end{array}$ & $\begin{array}{c}\text { Alternatif } \\
\text { Skor }\end{array}$ & $\begin{array}{c}\text { Jumlah } \\
\text { Responden } \\
\text { (Orang) }\end{array}$ & $\begin{array}{c}\text { Persentasi } \\
\text { Responden } \\
(\%)\end{array}$ & $\begin{array}{c}\text { Total } \\
\text { Skor }\end{array}$ \\
\hline Sangat & 5 & - & - & - \\
Puas & & 1 & 1.04 & 4 \\
Puas & 4 & 26 & 27.08 & 78 \\
Netral & 3 & 60 & 62.5 & 120 \\
Tidak & 2 & & & \\
$\begin{array}{l}\text { Puas } \\
\text { Sangat }\end{array}$ & 1 & 9 & 9.37 & 9 \\
Tidak & & & & \\
Puas & & & & \\
Total & & 96 & 100 & 211 \\
\hline Sumber : Diolah dari data primer & &
\end{tabular}

\section{Pernyataan Service}

Pelayanan yang diberikan oleh Restoran Pondok Hijau Kota Manado dilihat dari 5 instrumen pernyataab sebagai berikut :

\begin{tabular}{lllll}
\multicolumn{2}{l}{ Tabel. 28 Pernyataan Service } & & \\
\hline No & Pernyataan & Total & Indeks & Interpretasi \\
& Skor & Kepuasan & \\
& & Konsumen & \\
& & &
\end{tabular}

\begin{tabular}{|c|c|c|c|c|}
\hline 1 & $\begin{array}{l}\text { Kecepatan dalam } \\
\text { menyajikan produk } \\
\text { yang dipesan }\end{array}$ & 224 & $46.66 \%$ & Netral \\
\hline 2 & $\begin{array}{l}\text { Kesigapan } \\
\text { karyawan dalam } \\
\text { memberikan } \\
\text { pelayanan dalam } \\
\text { menangani keluhan } \\
\text { para konsumen } \\
\text { restoran pondok } \\
\text { hijau }\end{array}$ & 214 & $44.58 \%$ & Netral \\
\hline 3 & $\begin{array}{l}\text { Pengetahuan } \\
\text { karyawan terhadap } \\
\text { produk yang di jual }\end{array}$ & 214 & $44.58 \%$ & Netral \\
\hline 4 & $\begin{array}{l}\text { Keramahan } \\
\text { karyawan dalam } \\
\text { melayani }\end{array}$ & 211 & $43.95 \%$ & Netral \\
\hline 5 & $\begin{array}{lr}\text { Kerapihan } & \text { seragam } \\
\text { dari } & \text { karyawan } \\
\text { dalam melayani } \\
\text { konsumen }\end{array}$ & 210 & $43.75 \%$ & Netral \\
\hline
\end{tabular}

Sumber : Diolah dari data primer

Sesuai dengan hasil penelitian yang didapat dari 5 pernyataan service, konsumen memberikan penilaian yang kurang terhadap service atau pelayanan yang ada di Restotan Pondok Hijau Kota Manado dan ini menjadi bahan pertimbangan kepada pihak restoran agar dapat diperhatikan kembali.

\section{Rekapitulasi Indeks Persepsi Kepuasan Konsumen Pada Masing-masing Indikator Dan Interpretasi Hasil}

Penelitian mengukur Tingkat Kepuasan Konsumen Restoran Pondok Hijau Kota Manado, mengambil 18 indikator sebagai tolak ukur dengan total responden 96 konsumen dalam penelitian ini, dimana masing - masing terbagi dalam 5 (Lima) bagian dapat dilihat pada Tabel 29 .

Tabel. 29 Rekapitulasi Total Skor, Indeks Kepuasan dan Interpretasi Nilai

\begin{tabular}{|c|c|c|c|c|}
\hline No & Kategori & $\begin{array}{l}\text { Total } \\
\text { Skor }\end{array}$ & $\begin{array}{l}\text { Indeks } \\
\text { Kepuasan } \\
(\%) \\
\end{array}$ & $\begin{array}{l}\text { Interpre } \\
\text { tasi }\end{array}$ \\
\hline 1 & Product & 1280 & 88.88 & $\begin{array}{l}\text { Sangat } \\
\text { Puas }\end{array}$ \\
\hline 2 & Price & 1278 & 88.74 & $\begin{array}{l}\text { Sangat } \\
\text { Puas }\end{array}$ \\
\hline 3 & Place & 1706 & 88.85 & $\begin{array}{l}\text { Sangat } \\
\text { Puas }\end{array}$ \\
\hline 4 & Promotion & 1285 & 89.23 & $\begin{array}{l}\text { Sangat } \\
\text { Puas }\end{array}$ \\
\hline 5 & Service & 1073 & 44.70 & Netral \\
\hline
\end{tabular}

Untuk mengetahui letak kepuasan konsumen dalam tingkat kepuasan konsumen Restoran Pondok Hijau Kota Manado, maka perlu dihitung jumlah keseluruhan skor pada setiap kriterium, dimana sesuai hasil penelitian ini skor mencapai 6622. Pada penelitian ini, jumlah skor ideal (skor tertinggi), yaitu 8640 (tinggi) dan jumlah skor terendah yaitu 1728 (rendah), berdasarkan data yang diambil dari 18 intsrumen pernyataan yang diajukan kepada 96 responden. Berdasarkan indikator 5 yaitu service dapat dilihat bahwa total skornya, dengan total skor 1073, indeks kepuasan konsumen $44.70 \%$ (Netral) yang berarti kecepatan dalam menyajikan produk yang dipesan, kesigapan karyawan dalam memberikan pelayanan dalam menangani keluhan para konsumen restoran pondok hijau, pengetahuan karyawan terhadap produk yang dijual, kerapihan seragam karyawan dalam melayani konsumen dan keramahan karyawan dalam melayani. Namun indikator-indikator yang lain seperti : product, price, place, dan promotion, dengan penilaian dari konsumen, konsumen merasa sangat puas (SP), maka letak indeks Tingkat Kepuasan Konsumen Restoran Pondok Hijau Kota Manado terletak pada : 
Tingkat kepuasan konsumen

$=\frac{\text { Jumlah Skor Hasil Pengumpulan Data }}{\text { Jumlah skor ideal (tertinggi) }} \times 100 \%$

Tingkat kepuasan konsumen $=\frac{6622}{8640} \times 100 \%=76.64 \%$

Dengan interprestasi nilai :

Keterangan kriteria inerpretasi skor kepuasan Nasabah :

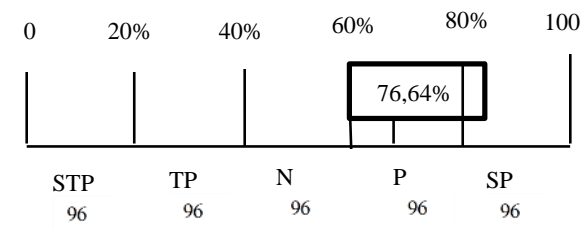

Angka $0 \%-20 \%=$ Sangat Tidak Puas

Angka 20\%-40\%= Tidak Puas

Angka $40 \%-60 \%=$ Netral

Angka $60 \%-80 \%=$ Puas

Angka $80 \%-100 \%=$ Sangat Puas

Berdasarkan hasil analisis menggunakan skala likert, maka dapat diketahui bahwa angka indeks Tingkat Kepuasan Konsumen Restoran Pondok Hijau Kota Manado berada pada titik $76.64 \%$ dan tergolong Puas (P).

\section{KESIMPULAN DAN SARAN}

\section{Kesimpulan}

Berdasarkan hasil penelitian yang telah didapat, dapat disimpulkan bahwa konsumen Restoran Pondok Hijau Kota Manado merasa Puas (P) terhadap product, price, place, promotion dan service yang ada dan di terapkan.

\section{Saran}

Untuk meningkatkan kepuasan konsumen pihak Restoran Pondok Hijau Kota Manado harus meningkatkan dan memperhatikan service, yakni penilaian tingkat kepuasan konsumen dalam hal service dikategori netral dan harus ditingkatkan pelayanannya agar penilaian konsumen bisa berada di kategori sangat puas dan puas. Sehingga konsumen akan merasa lebih nyaman dalam proses pelayanan yang ada di Restoran Pondok Hijau Kota Manado.

\section{DAFTAR PUSTAKA}

Amirulah, 2002. Perilaku Konsumen. Penerbit : Graha Ilmu.
Arisman, 2008. Analisis Kepuasan Konsumen Restoran Bumbu Desa Bogor. Skripsi. Fakultas Pertanian. IPB. Bogor.

Muliyadi.Nitisusastro. 2013. Perilaku konsumen dalam persepktif kewirausahaan. Alfabeta, CV.

Nugroho, 2003. Perilaku Konsumen. Perspektif Kontemporer Pada Motif, Tujuan Dan Keinginan Konsumen. PRENADAMEDIA GROUP, Jl. Tambra Raya No. 23 Rawamangun. Jakarta 13220.

Riduwan. 2012. Rumus dan data dalam analisis statistika. Penerbit alphabet.bandung.

Salimah. 2011. Analisis Kepuasan Dan Loyalitas Konsumen Martabak House Restorant (Studi Kasus : Cabang Pandega Marta, Kabupaten Sleman, Daerah Istimewa Yogyakarta). Skripsi Fakultas Ekonomi dan Manajemen IPB. Bogor.

Sangadji, E M dan Sopiah. 2013. Perilaku Konsumen. Pendekatan Praktis Disertai Jurnal Penelitian. Penerbit CV. ANDI OFFSET. Yogyakarta.

Sari, Adi Indah. Tingkat Kepuasan Konsumen Pada Mutu Pelayanan Rumah Makan (Studi Pada RM. Jawa Deli, RM. Putri Minang dan RM. Tak Bernama di Kampung Susuk, Kampus USU-Medan). Jurnal Keuangan dan Bisnis Vol. 4, No. 2, Juli 2012.

Schiffman dan kanuk. 2008. Perilaku Konsumen (Edisi ke Tujuh). Penerbit PT. Indeks.

Septina, Nova Rieski. 2008. Analisis Tingkat Kepuasan dan Loyalitas Konsumen Terhadap Minuman Teh Siap Minum (Ready To Drink) Merek Teh Botol Sosro di Jakarta Timur. Skripsi Fakultas Pertanian IPB. Bogor.

Sudjarwo, RA dkk. 2013. Analisis Pengaruh Kualitas Produk, Kualitas Pelayanan dan Lokasi Terhadap Kepuasan Konsumen.Jurnal Administrasi Bisnis administrasibisnis.studentjournal.ub.ac.id.(dia kses 3 Maret 2017).

Sunyoto Danang. 2014. Praktik Riset Perilaku Konsumen. CAPS (Center Of Academic Publishing Service. Jl. Cempaka Putih No 8 Yogyakarta).

Sujarweni, Wiratna V. 2014. Metodologi Penelitian. Pustaka Barupress. Yogyakarta.

Thesman, E dan I.G.B.R. Utama. 2010. Analisis Kinerja Menggunakan 7P (Marketing Mix). Fakultas Ekonomi Universitas Dhyana Pura, Bali. Kepuasan Pelanggan Terhadap Pelayanan PDAM Kota Denpasar. ISSN 1410-4628. Volume 12 No. 1. Jurnal. Fakultas Ekonomi Universitas Udayana, Denpasar Bali.

Yuliarmi \& Putu Riyasa, 2007. Pdf. Aanalisis FaktorFaktor Yang Mempengaruhi Kepuasan Pelanggan Terhadap Pelayanan PDAM Kota Denpasar. No ISSN 1410- 4628. 